\title{
Pengaruh Pemberian Latihan Soal Terstruktur Setelah Pembelajaran Langsung Terhadap Pemahaman Konsep Ikatan Ion Pada Siswa Kelas X IPA SMA Negeri 4 Palangka Raya Tahun Ajaran 2018/2019
}

\author{
Yuni Asi, Abudarin, Nopriawan Berkat Asi \\ Program Studi Pendidikan Kimia, FKIP, Universitas Palangka Raya, Indonesia
}

\begin{abstract}
Abstrak : Penelitian ini bertujuan untuk mendeskripsikan pengaruh pemberian latihan soal terstruktur setelah pembelajaran langsung terhadap pemahaman konsep Ikatan ion pada siswa kelas X IPA SMA Negeri 4 Palangka Raya tahun ajaran 2018/2019. Penelitian ini merupakan penelitian eksperimen dengan desain penelitian non ekuivalen pretest-posttest control group design dan melibatkan sebanyak 72 siswa dari dua kelas X IPA SMA Negeri 4 Palangka Raya sebagai sampel yang ditentukan dengan teknik cluster random sampling, yaitu siswa kelas X IPA-2 (kelas eksperimen) sebanyak 36 orang siswa dan siswa kelas X IPA-4 (kelas kontrol) sebanyak 36 orang siswa. Instrumen yang digunakan berupa soal tes pemahaman konsep (tes I dan tes II), latihan soal terstruktur, dan latihan soal tak terstruktur. Data tes I diperoleh setelah pembelajaran langsung dan data tes II diperoleh setelah pembelajaran menggunakan latihan soal terstruktur dan latihan soal tak terstruktur. Hasil penelitian menunjukkan bahwa "pemberian latihan soal terstruktur berpengaruh terhadap pemahaman konsep siswa tentang ikatan ion setelah pembelajaran langsung pada siswa kelas X IPA SMA Negeri 4 Palangka Raya Tahun Ajaran 2018/2019".
\end{abstract}

\section{Kata kunci: ikatan ion, latihan soal terstruktur}

\section{Pendahuluan}

Pendidikan yang terjadi saat ini tentu memiliki aturan dan dasar-dasar dalam penentuan sistem yang di pergunakan. Landasan sistem pendidikan tersebut diatur dalam UU No. 20 tahun 2013 tentang Sistem Pendidikan Nasional, pendidikan adalah usaha sadar dan terencana untuk mewujudkan suasana belajar dan proses pembelajaran agar peserta didik secara aktif mengembangkan potensi dirinya dengan cara mendorong dan memfasilitasi kegiatan belajar mereka, sehingga mampu menghadapi segala perubahan dan permasalahan dengan pendekatan-pendekatan kreatif tanpa harus kehilangan identitas dirinya.

Belajar adalah suatu proses usaha yang dilakukan seseorang untuk memperoleh perubahan tingkah laku yang baru secara keseluruhan, sebagai hasil pengalamannya sendiri dalam interaksi dengan lingkungan (Slameto, 2003). Ikatan ion adalah salah satu materi kimia yang diajarkan di SMA/MA. Terkadang materi ini hanya sebagai bahan hafalan bagi para siswa. Oleh karena itu, sangat diperlukan alternatif pembelajaran yang tepat agar siswa dapat memahami dan menguasai materi ikatan ion.

Berdasarkan latar belakang di atas, maka rumusan masalah dalam penelitian ini adalah "Apakah pemberian latihan soal terstruktur setelah pembelajaran langsung berpengaruh terhadap pemahaman konsep Ikatan ion pada siswa kelas X IPA SMA Negeri 4 Palangka Raya tahun ajaran 2018/2019?” Tujuan penelitian ini adalah untuk mendeskripsikan pengaruh pemberian latihan soal terstruktur setelah pembelajaran langsung terhadap pemahaman konsep 
Ikatan ion pada siswa kelas X IPA SMA Negeri 4 Palangka Raya tahun ajaran 2018/2019.

Belajar tidak hanya mempelajari mata pelajaran, tetapi juga penyusunan, kebiasaan, persepsi, kesenangan atau minat, penyesuaian sosial, bermacammacam keterampilan lain, dan cita-cita (Hamdani, 2011). Belajar konsep merupakan hasil utama pendidikan. Konsep merupakan batu pembangun berfikir dan dasar bagi proses mental yang lebih tinggi untuk merumuskan prinsip dan generelisasi. Untuk memecahkan masalah, seorang siswa harus mengetahui aturan-aturan yang relevan dan aturan-aturan ini didasarkan pada konsep-konsep yang diperolehnya (Dahar, 2011). Pemahaman konsep diartikan sebagai kemampuan untuk menyerap arti dari materi atau bahan yang dipelajari (Susanto, 2013).

Model pembelajaran langsung merupakan salah satu pendekatan mengajar yang di rancang khusus untuk menunjang proses belajar siswa yang berkaitan dengan pengetahuan deklaratif dan pengetahuan prosedural, yang terstruktur dengan baik yang dapat diajarkan dengan pola kegiatan betahap, selangkah demi selangkah (Trianto, 2011). Lembar kerja siswa adalah panduan siswa yang digunakan untuk melakukan kegiatan penyelidikan atau pemecahan masalah. LKS memuat sekumpulan kegiatan mendasar yang harus dilakukan oleh, siswa untuk memaksimalkan pemahaman dalam upaya pembentukan kemampuan dasar sesuai indikator pencapaian hasil belajar yang harus di tempuh (Trianto, 2009).

Ikatan ion adalah ikatan yang terjadi akibat perpindahan elektron dari satu atom ke atom lain. Menurut teori Lewis dan Kossel, ikatan ion terjadi antara ion positif (atom yang melepaskan elektron) dan ion negatif (atom yang menangkap elektron) (Endang, 2014). Ion positif terbentuk karena suatu atom melepaskan elektron. Atom yang cenderung melepaskan elektronnya adalah atom logam. Ion negatif terbentuk karena suatu atom menangkap elektron. Atom yang cenderung menangkap elektron adalah atom non logam. Ikatan ion adalah ikatan antara ion positif dan ion negatif. Ikatan ion terbentuk antara atom yang melepaskan elektron (logam) dengan atom yang menangkap elektron (non logam).

Konsep ikatan ion merupakan jenis pengetahuan prosedural yang akan dipahami dengan baik jika siswa banyak diberikan latihan soal. Asumsi didalam penelitian ini adalah siswa bersungguh-sungguh mengikuti pembelajaran dan mengerjakan tes, siswa tidak melihat buku dan tidak melihat jawaban teman. Hipotesis yang diajukan pada penelitian ini adalah terdapat pengaruh pemberian latihan soal terstruktur terhadap pemahaman konsep Ikatan ion siswa kelas X IPA SMA Negeri 4 Palangka Raya Tahun Ajaran 2018/2019.

\section{Metode Penelitian}

Pengambilan data ini dilaksanakan di sekolah SMA Negeri 4 Palangka Raya Penelitian ini dilakukan pada 13 Agustus 2018. Dalam penelitian ini diambil dua kelas sebagai kelas sampel yaitu kelompok kelas eksperimen dan kelompok kelas kontrol. Kelompok kelas eksperimen adalah kelas X IPA-1 dan kelompok kelas kontrol adalah kelas X IPA-3 SMA Negeri 4 Palangka Raya.

Jenis penelitian ini adalah penelitian kuantitatif yang menggunakan sampel. Penelitian ini terbagi dalam dua kelas, yaitu kelas eksperimen dan kelas kontrol. Metode penelitian yang digunakan dalam penelitian ini adalah metode eksperimen. Menurut Sugiyono (2010) metode eksperimen adalah metode 
penelitian yang digunakan untuk mencari pengaruh perlakuan tertentu terhadap yang lain dalam kondisi yang terkendalikan, dalam penelitian ini dilakukan suatu percobaan dengan memberikan perlakuan-perlakuan dan membandingan pengaruh-pengaruh perlakuan tersebut terhadap sampel yang dipilih.

Variabel bebas adalah jenis latihan soal yaitu latihan soal terstruktur yang dilanjutkan setelah pembelajaran langsung. Variabel terikat adalah pemahaman konsep siswa pada materi Ikatan ion yang diukur dari skor hasil tes siswa. Desain eksperimen penelitian ini adalah non ekuivalen pretest-posttest control group design (Sugiyono, 2012) yang digambarkan pada Tabel 1.

Tabel 1. Desain Penelitian

\begin{tabular}{|c|c|c|c|c|}
\hline Kelompok & Pembelajaran & $\begin{array}{c}\text { Tes awal (tes } \\
\text { I) }\end{array}$ & Perlakuan & $\begin{array}{c}\text { Tes Akhir (tes } \\
\text { II) }\end{array}$ \\
\hline $\begin{array}{c}\text { Eksperimen } \\
\text { (E) }\end{array}$ & $\mathrm{P}_{1}$ & $X_{e}$ & $\mathrm{~T}_{1}$ & $\mathrm{Y}_{\mathrm{e}}$ \\
\hline Kontrol (K) & $\mathrm{P}_{1}$ & $X_{k}$ & $\mathrm{~T}_{0}$ & $Y_{k}$ \\
\hline $\begin{array}{l}\text { Keterangan }: \\
\mathrm{T}_{1}=\text { Pembela } \\
\mathrm{T}_{0}=\text { Pembela } \\
\mathrm{X}_{\mathrm{e}}=\text { Skor has } \\
\mathrm{X}_{\mathrm{k}}=\text { Skor has } \\
\mathrm{Y}_{\mathrm{e}}=\text { Skor has } \\
\mathrm{Y}_{\mathrm{k}}=\text { Skor has } \\
\mathrm{P}_{1}=\text { Pembela }\end{array}$ & $\begin{array}{l}\text { an dengan meng } \\
\text { an dengan meng } \\
\text { tes kemampuan a } \\
\text { tes kemampuan a } \\
\text { tes kemampuan a } \\
\text { tes kemampuan a } \\
\text { an langsung }\end{array}$ & $\begin{array}{l}\text { Inakan latihan s } \\
\text { anakan latihan s } \\
\text { al kelas eksper } \\
\text { val kelas kontro } \\
\text { hir kelas eksper } \\
\text { hir kelas kontro }\end{array}$ & $\begin{array}{l}\text { al terstruktur } \\
\text { al tak terstruk } \\
\text { nen } \\
\text { nen }\end{array}$ & \\
\hline
\end{tabular}

Populasi dalam penelitian ini adalah seluruh siswa kelas X IPA semester I di SMA Negeri 4 Palangka Raya tahun ajaran 2018/2019. Populasi ini terdiri dari 6 kelas X IPA-1, X IPA-2, X IPA-3, X IPA-4, X IPA-5, X IPA-6. Pengambilan sampel dilakukan dengan teknik cluster random sampling. Dalam penelitian ini diambil dua kelas sebagai sampel yaitu kelompok kelas eksperimen dan kelompok kelas kontrol. Kelompok kelas eksperimen yang dipilih adalah kelas X IPA-2 dan kelompok kelas kontrol yang dipilih adalah kelas X IPA-4.

Instrumen penelitian dilakukan uji validitas, indeks kesukaran, daya pembeda soal, reliabilitas instrumen penelitian. Data yang diperlukan dalam penelitian ini yaitu data kuantitatif berupa skor hasil tes belajar siswa kelas $\mathrm{X}$ IPA-2 dan X IPA-4 SMA Negeri 4 Palangka Raya Semester I tahun ajaran 2018/2019 dalam menyelesaikan soal ikatan ion. Pengumpulan data dalam penelitian ini menggunakan metode dokumentasi dan metode eksperimen. Metode dokomentasi untuk mendaftar nama siswa, jumlah siswa, dan nilai ulangan harian siswa tengah semester siswa kelas X IPA di SMA Negeri 4 Palangka Raya tahun ajaran 2018/2019 untuk mengetahui kemampuan kelas eksperimen dan kelas kontrol tidak jauh berbeda. Data yang diperoleh dianalisis untuk menentukan uji normalitas dan uji homogenitas. Sedangkan metode eksperimen yang digunakan dalam penelitian ini pada tahap pertama yaitu, memberikan pembelajaran langsung pada kelas eksperimen dan kelas kontrol kemudian setelah pembelajaran dilakukan tes pertama (tes I) untuk memperoleh data pemahaman konsep awal siswa. Tahap kedua memberikan perlakuan pada kelas eksperimen yaitu dengan memberikan latihan soal yang disertai dengan 
langkah-langkah penyelesaian secara terstruktur (latihan soal terstruktur), dan kelas kontrol diberikan latihan soal tanpa langkah penyelesian soal (latihan soal tak terstruktur), setelah pembelajaran selesai dilakukan tes kedua (tes II ) pada kedua kelas tersebut.

Data tes I didapat sebelum perlakuan. Dan data tes II didapat setelah perlakuan. Perlakuan yang digunakan yaitu pembelajaran menggunakan latihan soal terstruktur pada kelas eksperimen dan pembelajaran menggunakan latihan soal tak terstruktur pada kelas kontrol. Uji Normalitas adalah untuk menguji normal tidaknya distribusi data pada sampel. Uji homogenitas digunakan menguji apakah populasi penelitian mempunyai varian yang sama. Uji keseimbangan menggunakan data tes awal (tes I) materi ikatan ion pada kelas eksperimen dan kelas kontrol, uji keseimbangan dilakukan untuk mengetahui data kemampuan awal kedua kelas apakah seimbang atau tidak, maka dilakukan uji normalitas untuk mengetahui normal atau tidaknya distribusi data pada sampel dan uji homogenitas digunakan untuk menentukan uji-t yang digunakan untuk mengetahui keadaan awal kedua sampel.

\section{Hasil Penelitian Dan Pembahasan}

Tes I dilakukan setelah pembelajaran langsung dan tes II didapatkan setelah pembelajaran menggunakan latihan soal terstruktur.

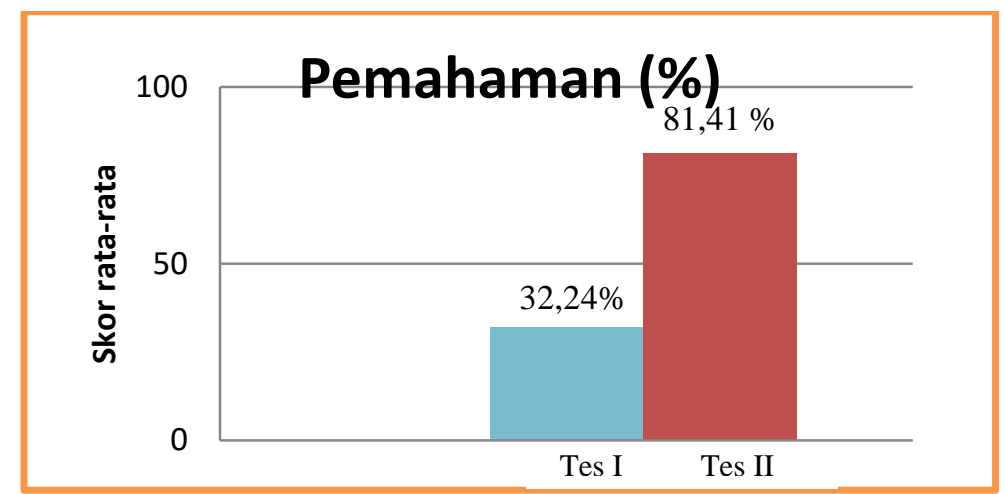

Gambar 1. Data Pemahaman Siswa pada Tes I dan Tes II Kelas Eksperimen

Tes I dilakukan setelah pembelajaran langsung dan tes II didapatkan setelah pembelajaran menggunakan latihan tak soal terstruktur.

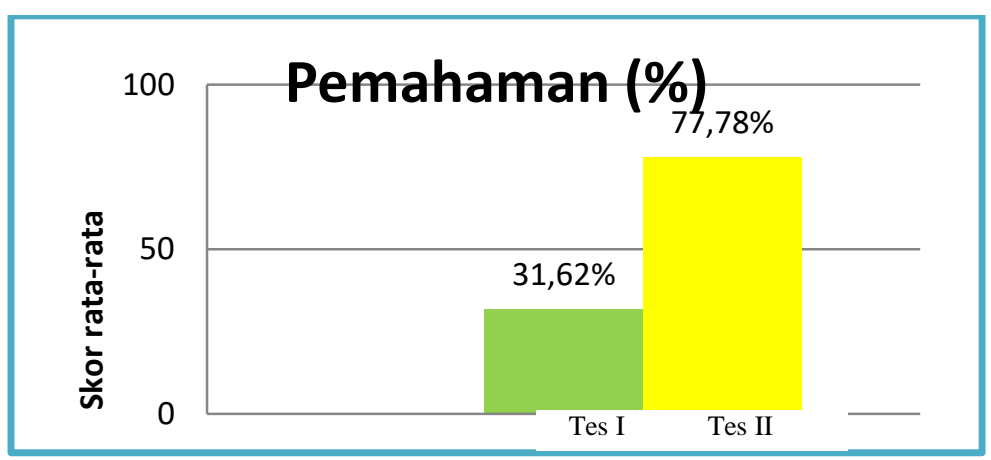

Gambar 2. Data Pemahaman Siswa pada Tes I dan Tes II Kelas Kontrol

Tabel 2. Distribusi Frekuensi Tes I (tes awal) Kelas Kontrol 


\begin{tabular}{ccccccc}
\hline $\begin{array}{c}\text { Banyak } \\
\text { kelas }\end{array}$ & Interval & $\begin{array}{c}\text { Batas } \\
\text { atas }\end{array}$ & F & FK & F (\%) & FK (\%) \\
\hline 1 & $0-11$ & 11,5 & 7 & 7 & 19,44 & 19,44 \\
\hline 2 & $12-23$ & 23,5 & 9 & 16 & 25,00 & 44,44 \\
\hline 3 & $24-35$ & 35,5 & 5 & 21 & 13,89 & 58,33 \\
\hline 4 & $36-47$ & 47,5 & 4 & 25 & 11,11 & 69,44 \\
\hline 5 & $48-59$ & 59,5 & 4 & 29 & 11,11 & 80,55 \\
\hline 6 & $60-71$ & 71,5 & 7 & 36 & 19,44 & 100 \\
\hline Jumlah & & & 36 & & 100 & \\
\hline
\end{tabular}

Tabel 2 menunjukkan distribusi frekuensi tes I (tes awal) kelas kontrol bahwa sebanyak 16 orang siswa atau $44,44 \%$ siswa mendapat nilai di bawah ratarata dan sebanyak 20 orang siswa atau $55,56 \%$ siswa mendapat nilai di atas ratarata.

Tabel 3. Distribusi Frekuensi Tes II (tes akhir) Kelas Kontrol

\begin{tabular}{ccccccc}
\hline $\begin{array}{c}\text { Banyak } \\
\text { kelas }\end{array}$ & Interval & $\begin{array}{c}\text { Batas } \\
\text { atas }\end{array}$ & F & FK & F (\%) & FK (\%) \\
\hline 1 & $23-35$ & 35,5 & 2 & 2 & 5,56 & 5,56 \\
\hline 2 & $36-48$ & 48,5 & 2 & 4 & 5,56 & 11,12 \\
\hline 3 & $49-61$ & 61,5 & 1 & 5 & 2,78 & 13,89 \\
\hline 4 & $62-74$ & 74,5 & 7 & 12 & 19,44 & 33,34 \\
\hline 5 & $75-87$ & 87,5 & 11 & 23 & 30,56 & 63,89 \\
\hline 6 & $88-100$ & 100,5 & 13 & 36 & 36,11 & 100 \\
\hline Jumlah & & 36 & & 100 & \\
\hline
\end{tabular}

Tabel 3 menunjukkan distribusi frekuensi tes II (tes akhir) kelas kontrol bahwa sebanyak 12 orang siswa atau 33,33\% siswa mendapat nilai di bawah ratarata dan sebanyak 24 orang siswa atau $66,67 \%$ siswa mendapat nilai di atas ratarata.

Tabel 4. Uji Normalitas Data Tes I (tes awal) Kelas Eksperimen dan Kelas Kontrol

\begin{tabular}{cccccc}
\hline Data Tes I & $\mathbf{N}$ & $\mathbf{A}$ & $\chi_{\text {hitung }}^{2}$ & $\chi_{\text {tabel }}^{2}$ & Kesimpulan \\
\hline Kelas Eksperimen & 36 & 0,05 & 6,64 & 11,07 & Normal \\
\hline Kelas Kontrol & 36 & 0,05 & 4,85 & 11,07 & Normal \\
\hline
\end{tabular}

Berdasarkan hasil perhitungan uji-t dari data tes awal (tes I) kedua sampel diperoleh nilai $t_{\text {hitung }}=0,67$ sedangkan $t_{\text {tabel }}=1,67$ dengan $d b=n_{1}+n_{2}-2=70$ pada taraf signifikan 5\%. Jadi $t_{\text {hitung }}<t_{\text {tabel }}$ sehingga $\mathrm{H}_{0}$ diterima dan $\mathrm{H}_{\mathrm{a}}$ ditolak. Dengan demikian dapat disimpulkan bahwa tidak terdapat perbedaan rata-rata kemampuan awal siswa tentang konsep Ikatan ion pada kelas eksperimen dan kelas kontrol atau sebelum siswa mengerjakan latihan soal terstruktur.

Tabel 5. Uji Normalitas Data Tes II (tes akhir) Kelas Eksperimen dan Kelas Kontrol

\begin{tabular}{cccccc}
\hline Data Tes II & N & A & $\chi_{\text {hitung }}^{2}$ & $\chi_{\text {tabel }}^{2}$ & Kesimpulan \\
\hline Kelas Eksperimen & 36 & 0,05 & 9,96 & 11,07 & Normal \\
\hline Kelas Kontrol & 36 & 0,05 & 6,25 & 11,07 & Normal \\
\hline
\end{tabular}


Hipotesis penelitian dalam penelitian ini adalah sebagai berikut :

$\mathrm{H}_{\mathrm{o}}$ : Pemberian latihan soal terstruktur tidak berpengaruh terhadap pemahaman konsep Ikatan ion siswa kelas X IPA SMA Negeri 4 Palangka Raya.

$\mathrm{H}_{\mathrm{a}}$ : Pemberian latihan soal terstruktur berpengaruh terhadap pemahaman konsep Ikatan ion siswa kelas X IPA SMA Negeri 4 Palangka Raya.

Hipotesis statistik dalam penelitian ini menggunakan uji-t (dua pihak) dengan taraf signifikan 5\% sebagai berikut :

$\mathrm{H}_{\mathrm{o}}:\left(\mu_{1}=\mu_{0}\right) \quad$ Tidak terdapat perbedaan rata-rata nilai pemahaman konsep Ikatan ion siswa kelas X IPA-2 dengan siswa kelas X IPA-4.

$\mathrm{H}_{\mathrm{a}}:\left(\mu_{1} \neq \mu_{0}\right) \quad$ Terdapat perbedaan rata-rata nilai pemahaman konsep Ikatan ion siswa kelas X IPA-2 dengan siswa kelas X IPA-4.

Dimana :

$\mu_{1} \quad$ : Rata-rata nilai pemahaman konsep siswa tentang ikatan ion setelah pembelajaran langsung dilanjutkan latihan soal terstruktur.

$\mu_{0} \quad$ : Rata-rata nilai pemahaman konsep siswa tentang ikatan ion setelah pembelajaran langsung dilanjutkan latihan soal tak terstruktur.

Berdasarkan hasil perhitungan uji-t dari data tes akhir (tes II) kedua sampel diperoleh nilai $t_{\text {hitung }}=4,27$ sedangkan $t_{\text {tabel }}=1,67$ dengan $d b=n_{1}+n_{2}-2$ $=70$ pada taraf signifikan 5\%. Hasil analisis tersebut menyebutkan $t_{\text {hitung }}>t_{\text {tabel }}$ maka $\mathrm{H}_{0}$ ditolak dan $\mathrm{H}_{\mathrm{a}}$ diterima. Dengan demikian dapat disimpulkan bahwa pemberian latihan soal terstruktur berpengaruh terhadap pemahaman konsep Ikatan ion siswa kelas X IPA SMA Negeri 4 Palangka Raya Tahun Ajaran 2018/2019.

Penelitian ini dilaksanakan pada dua kelas yaitu kelas eksperimen dan kelas kontrol, dimana kelas eksperimen diberikan perlakuan berupa pembelajaran menggunakan latihan soal disertai langkah penyelesaian soal (latihan soal terstruktur) sedangkan kelas kontrol diberikan perlakuan berupa pembelajaran menggunakan latihan soal tanpa langkah penyelesaian soal (latihan soal tak terstruktur). Penelitian ini bertujuan untuk menganalisis pengaruh pemahaman hasil belajar siswa antara kelas yang menggunakan latihan soal terstruktur dengan kelas yang menggunakan latihan soal tak terstruktur. Berdasarkan hasil wawancara terhadap guru mata pelajaran kimia SMA Negeri 4 Palangka Raya dan rata-rata hasil ulangan semester, sebelum pengambilan data diketahui bahwa kemampuan yang dimiliki oleh kelas eksperimen dan kelas kontrol tidak berbeda secara signifikan. Hal ini terbukti dari hasil perhitungan uji keseimbangan pada tes I kelas eksperimen dan kelas kontrol. Pelaksanaan tes I dan tes II diberikan alokasi waktu yang sama yaitu \pm 25 menit dengan jumlah soal masing-masing 3 butir soal essay. Tes I dilakukan setelah pembelajaran langsung diikuti 36 orang siswa untuk kelas eksperimen dan 36 orang siswa untuk kelas kontrol. Tes II dilakukan setelah pembelajaran menggunakan latihan soal terstruktur pada kelas eksperimen dan latihan soal tak terstruktur pada kelas kontrol data pemahaman siswa tes I dan tes II. 
Tabel 6. Perubahan Pemahaman Konsep Siswa pada Setiap Indikator

\begin{tabular}{lccccc}
\hline \multirow{2}{*}{ Indikator } & No soal & \multicolumn{2}{c}{ Kelas Eksperimen } & \multicolumn{2}{c}{ Kelas Kontrol } \\
\cline { 3 - 6 } & 1 & 41,67 & 92,22 & 42,22 & 85,00 \\
\hline $\begin{array}{l}\text { Memprediksi sifat unsur logam } \\
\text { dan non logam berdasarkan }\end{array}$ & 2 & Tes II & Tes I & Tes II \\
$\begin{array}{l}\text { konfigurasi elektron dan } \\
\text { elektron valensi }\end{array}$ & 3 & 22,92 & 75,00 & 18,06 & 69,44 \\
\hline $\begin{array}{l}\text { Menjelaskan proses } \\
\text { terbentuknya ikatan ion }\end{array}$ & 28 & 84,03 & 34,03 & 81,25 \\
\hline $\begin{array}{l}\text { Mengidentifikasi pasangan } \\
\text { unsur-unsur yang dapat } \\
\text { membentuk ikatan ion }\end{array}$ & \multicolumn{1}{c}{ Rata-rata Indikator } & $\mathbf{3 4 , 9 5}$ & $\mathbf{8 3 , 7 5 \%}$ & $\mathbf{3 1 , 4 4}$ & $\mathbf{7 8 , 5 6 \%}$ \\
\hline \multicolumn{1}{c}{} & & & & & \\
\hline
\end{tabular}

Ringkasan pemahaman konsep siswa pada setiap indikator ditunjukkan pada Tabel 6. Rata-rata perubahan pemahaman konsep kelas eksperimen sebesar $83,75 \%$ dan rata-rata perubahan pemahaman konsep kelas kontrol sebesar $78,56 \%$

\section{Kesimpulan}

Hasil uji statistik menggunakan uji-t pada taraf signifikan 5\%, menunjukkan bahwa pemberian latihan soal terstruktur berpengaruh terhadap pemahaman konsep siswa tentang ikatan ion setelah pembelajaran langsung pada siswa kelas X IPA SMA Negeri 4 Palangka Raya Tahun Ajaran 2018/2019.

\section{Daftar Rujukan}

Arikunto, S. 2007. Dasar-dasar Evaluasi Pendidikan. Jakarta: Bumi Aksara. Azhar, Arsyad. 2014. Media Pembelajaran. Jakarta: PT Raja Gravindo Persada. Dahar, R. W. 2011. Teori-Teori Belajar dan Pembelajaran. Jakarta: Erlangga.

Dwi, Yunita. 2014. Peningkatan Pemahaman Konsep Ikatan Kovalen dengan Menggunakan LKS Latihan Soal Terstruktur Pada Siswa Kelas X SMA Negeri 1 Sanaman Mantikei Tumbang Kaman Tahun Ajaran 2013/2014. Skripsi sarjana, tidak diterbitkan. Universitas Palangka Raya.

Endang, S. 2014. Kimia 1 Untuk Kelas X SMA dan MA. Solo: PT.Wangsa Jatra Lestari.

Hamdani. 2011. Strategi Belajar Mengajar. Bandung: Pustaka Setia.

Khairani, Makmun. 2014. Psikologi Belajar. Yogyakarta: Aswaja Pressindo

Mairing, Jackson Pasini. 2017. Statistika Pendidikan. Yogyakarta: CV. Andi Offset.

Majid, Abdul. 2015. Strategi Pembelajaran. Bandung: Rosda.

Oktami, Vevi. 2015. Pemahaman Konsep Ikatan Ion Pada Siswa Kelas XTEKNIK MESIN SMK Negeri 1 Palangka Raya Tahun Ajaran 2014/2015 Dalam Pembelajaran Menggunkan LKS-Latihan Soal Terstruktur. Skripsi sarjana, tidak diterbitkan. Universitas Palangka Raya.

Prastowo, Andi. 2015. Panduan Kreatif Membuat Bahan Ajar Inovatif. Yogyakarta: Diva Press.

Rika, Agus Parlin. 2014. Analisis Pemahaman Konsep Ikatan Ion Pada Siswa Kelas X Pembelajaran Menggunakan LKS-Latihan Soal Terstruktur di 
SMA Negeri 1 Sanaman Mantikei Tumbang Kaman Tahun Ajaran 2013/2014. Skripsi sarjana, tidak diterbitkan. Universitas Palangka Raya.

Sastra. 2010. Pembelajaran "Blended Learning”. Diunduh Pada tanggal 10

Desember 2018

dari

http://matematikablendedlearning.blogspot.com//2010/11/lembar-kerjasiswa-lks-terstruktur.html.

Slameto. 2003. Belajar dan Faktor-faktor yang Mempengaruhinya. Jakarta: Rineka Cipta.

Sudarmo, Unggul. 2016. Kimia untuk SMA/MA kelas X. Jakarta: Erlangga.

Sugiyono. 2010. Metode Penelitian Pendidikan Pendekatan Kuantitatif, Kulaitatif dan $R \& D$. Bandung: Cv. Alfa Beta.

Susanto, A. 2013. Teori Belajar dan Pembelajaran. Jakarta: Kencana Prenadamedia Group Sudjana.

Tim Penulis Buku Pedoman Skripsi FKIP UPR. 2017. Pedoman Penulisan Skripsi. Palangka Raya : Universitas Palangka Raya.

Trianto. 2011. Model-model Pembelajaran Inovatif Berorientasi Konstruksi. Jakarta: Prestasi Pustaka. 